\title{
University students' digital competence in three areas of the DigCom 2.1 model: A comparative study at three European universities
}

\author{
Eloy López-Meneses \\ University of Pablo de Olavide, Spain \\ Fabrizio Manuel Sirignano \\ Università degli Studi Suor Orsola Benincasa, Italy \\ Esteban Vázquez-Cano \\ Universidad Nacional de Educación a Distancia, Spain
}

José M. Ramírez-Hurtado

University of Pablo de Olavide, Spain

\begin{abstract}
This study analysed the digital competence of 1,073 students at one Italian and two Spanish universities using the COBADI 2.0 (Basic Digital Competences/Registered Trademark 2970648) questionnaire. A quantitative methodology was applied to university students' use of, and competence in, three areas of DigCom 2.1: information and data literacy, communication and collaboration, and digital content creation. The results showed that these future graduates had an upper intermediate level of competence in information and digital literacy, and communication and collaboration, but a lower intermediate level in terms of digital content creation, particularly in the creation and dissemination of multimedia content using different tools. Two student profiles were identified for time spent online: those who dedicated a lot of their time to gaming or interacting on social media, and those who used most of their online time to searching for information and completing academic work.
\end{abstract}

\section{Implications for practice or policy:}

- Two student profiles were identified for time spent on the internet: gaming or interacting on social media, and searching for information and complete academic work.

- Information and data literacy, and communication and collaboration are the competences more developed among university students.

- The students' skill to create multimedia content need to be improved.

- Creativity when generating audiovisual material is essential to code content and information in academic, personal and professional contexts.

Keywords: information and communication technology, digital content creation, DigCom 2.1, digital competence, quantitative analysis.

\section{Introduction}

The dynamic of the society in which we live today requires our education systems to adopt a new approach to forming our future professionals: one that takes account of global economic development and the demands of an increasingly volatile job market. The traditional model based on knowledge transmission and memorisation needs to be replaced by other methodologies that allow students to acquire knowledge, skills, and attitudes that are applicable to a work environment and real and relevant to them (European Commission, 2016; Fernández, Leiva, \& López Meneses, 2017; Organisation for Economic Co-operation and Development (OECD), 2005; United Nations Educational, Scientific and Cultural Organization (UNESCO), 2011).

The European Commission $(2007,2018)$ defines digital competence as one of the nine key competences that enable citizens to participate actively in society, stating that "digital competence means the safe, critical and responsible use of, and the commitment to, digital technologies for learning, working and for participation in society" (2018, p.5). Today, technology is a constant feature of our lives, with the 
prevalence of synchronic conversation systems as a means of communication, social networks as relationship contexts, and context repositories as collaborative spaces for users to develop their creativity (López-Gil \& Bernal-Bravo, 2019; Mosa, Naz'ri bin Mahrin, \& Ibrrahim, 2016; Sharkova, 2014). Processes of communication now take place in a multiscreen environment where media and digital resources are essential on a professional, social, economic, political, or entertainment level, meaning that educational institutions cannot remain aloof from this media context (Armellini, \& De Stefani, 2015; Bhuasiri, Xaymoungkhoun, Zo, Jeung, \& Ciganek, 2012; Gozálvez, García-Ruiz, \& Aguaded, 2014). Developing digital competence in university students is vital for the success of the educational process in higher education. Good digital competence enables students to acquire a greater capacity to interpret and understand while online (Mosa et al., 2016) and can help them progress in academic, personal and professional environments, to operate in virtual collaborative work scenarios (Gunawardena et al., 2001), and perform better in online education (Barber, DiGuiseppe, vanOostveen, Blayone, \& Koroluk, 2016).

The general aim of this investigation was to analyse university students' digital competence in three aspects of DigCom 2.1 (Carretero, Vuorikari, \& Punie, 2017). The specific aims were: (1) to analyse university students' online time distribution in relation to technology consumption, and discover possible differences between the students at the three universities; (2) to analyse the students' digital competence in searching for, and treatment of, information; and (3) to study ICT use in the university context as a virtual and social communication tool. In each case, that analysis considered the information as a whole and then the differences that might exist between students from the two countries.

\section{University students' digital competences}

Today's society demands new forms of social, political, economic, and educational life organisation, thus the need for new professionals endowed with a broad skill set that includes digital competence (Cabero, Vázquez-Cano, \& López Meneses, 2018; Marín-Díaz, Reche, \& Maldonado, 2013). Various authors have defined a competence as a process that enables people to resolve problems creatively, perform activities, formulate questions, search for relevant information, and analyse, understand, and reflect as they apply their knowledge in response to the demands of a real world (Bancroft, 2016; Newland \& Handley, 2016; Ramos, Chiva, \& Gómez, 2017; Serrano, Biedermann, \& Santolaya, 2016). It could be said that we are facing a paradigmatic shift in the process of educating professionals (Barlow-Jones \& van der Westhuizen, 2011; Bendermacher, Oude Egbrink, Wolfhagen, \& Dolmans, 2017). As González-Calatayud, RománGarcía, and Prendes-Espinosa (2018) stated, given the importance of competences and their place at the centre of the progressive approach adopted by our educational systems, official institutions have begun to list the basic competences required of students, all of which include digital competence (European Commission, 2006, 2016; European Union, 2014; Organic Law of Education, 2006; OECD, 2005; UNESCO, 2011). Digital competence can be understood as the capacity to know how to use technology efficiently in order to improve all areas of our daily lives. Yet digital competence is not just an isolated skill to be developed but a range of skills, abilities, and attitudes to be deployed across different areas and dimensions of knowledge (Ferrari, Neza, \& Punie, 2014; Rodríguez-García, Raso-Sánchez, \& RuizPalmero, 2019; Vázquez-Cano, 2014). From the European Union framework of key competences for all citizens, digital competence is one of eight key competences and it is defined as follows:

Digital competence involves the confident and critical use of Information Society Technology (IST) for work, leisure and communication. It is underpinned by basic skills in ICT: the use of computers to retrieve, assess, store, produce, present and exchange information, and to communicate and participate in collaborative networks via the Internet. (European Commission, 2006, p. 16)

The European Parliament's own definition states that digital competence:

[E]ntails the safe and critical use of information society technologies (IST) for work, leisure and communication. It is based on ... the use of computers in order to obtain, evaluate, store, produce, present and exchange information, and communicate and participate in collaborative networks through Internet. (European Commission, 2006, p. 15) 
Digital competences encompass:

$[\mathrm{K}]$ nowledge of the main computer applications, ... understanding of the potential risks and opportunities of Internet and communication via electronic media, ... the capacity to search for, obtain and treat information, ... interest in participating in communities and networks with cultural, social or professional objectives. (European Commission, 2006, p. 16)

Furthermore, it has been proposed that in our interconnected world "sustainable development and social cohesion depend critically on the competences of all of our population - with competences understood to cover knowledge, skills, attitudes and values" (OECD, 2005, p. 4).

One of the first definitions of digital literacy was introduced by Gilster (1997) as "the ability to understand and use information in multiple formats from a wide range of sources when it is presented via computers" (p. 1). As Spante, Hashemi, Lundin, \& Algers (2018; p. 10-11) established in their systematic review about definition of digital competence, different authors proposed the concepts of "search for and access data", "interact through a variety of digital technologies" and "create and edit digital content" as fundamental items of digital competence definition. Thus, Parvathamma and Pattar (2013, p. 159) define digital literacy as the "[a]bility to use ICT tools and internet access, manage, integrate, evaluate, create and communicate information to function in a knowledge society". Bancroft (2016) combines policy document with research when using the following definition of digital literacy as encompassing "a continuum of skills, beginning with basic operational tasks progressing to more complex critical production and consumption of digital material" (p. 49). In general, publications focuses on the abilities, or skills, necessary to develop to be able to use ICT tools (Parvathamma \& Pattar, 2013). In other publications (e.g., Blas Padilla, Vázquez-Cano, Morales Cevallos, \& López Meneses, 2019; López Meneses, Vázquez-Cano, \& Fernández Márquez, 2014), such abilities as identify, access, evaluate, and synthesis are also stressed, but their definitions also include individual awareness of, and attitude to, using such tools appropriately, and ability to reflect on the process of using such tools.

It is interesting to see how far the concept of digital competence has evolved, from a merely functional perspective of the individual's capacity to perform certain technical tasks, to a concept that embraces the capacity to understand, integrate, and utilise the information available on any digital device derived from many sources and in a wide variety of formats (Bawden, 2008; Brečko, \& Ferrari, 2016; Daniel, VázquezCano, \& Gisbert, 2015; López Meneses, Vázquez-Cano, \& Jaén Martínez, 2017). Today’s students have to learn to handle this entire technological society and the intrinsic process of digitalisation that has transformed the ways we communicate, learn, and access work. In other words, they must live in the present and at the same time be prepared for the future (Bennett, 2014; Buchanan, Sainter, \& Saunders, 2013; Cronin, 2017; Gisbert \& Lázaro, 2015; Vázquez-Cano, 2013). In Ferrari’s (2012) report, digital competence is defined as:

[A] set of knowledge, skills, attitudes, strategies and awareness which are required when ICT and digital media are used to perform tasks, resolve problems, communicate, manage information, collaborate, create and share content, and build knowledge in an effective, efficient and adequate way, in a critical, creative, autonomous, flexible, ethical and a sensible form for work, entertainment, participation, learning, socialisation, consumption and empowerment. (p. 3)

Thus, to develop this research, we used the DigComp 2.1 proposal as a reference (Carretero et al., 2017). DigComp clusters the basic digital competence framework for citizens (DSC) into 5 competence areas, including 21 competences evaluated over eight proficiency levels, described in terms of learning outcomes and including examples of use. Our study focuses on the first three of these areas of competence. The first, information and data literacy, is the competnece to articulate information needs, search for and access data, information, and content in digital environments, and to navigate between them, and to create and update personal search strategies. The second, communication and collaboration, is the competence to interact through a variety of digital technologies and to understand the appropriate digital communication means for a given context. The third, digital content creation, is the competence to create and edit digital content in different formats, to express oneself through digital means. 


\section{Method}

The data were gathered via the University Students' Basic Digital Competences 2.0 COBADI® questionnaire (registered at the Spanish Patent and Trademark Office. $\mathrm{N}^{\circ}$ 2970648). This survey was created and tested by members of the EDUINNOVAGOGÍA ${ }^{\circledR}$ (HUM-971) research group, recognised by the Andalusian Plan for Research, Development and Innovation, and the Research Results Transfer Office at the Universidad Pablo de Olavide (UPO) de Sevilla (Spain). The questionnaire consisted of 22 items divided in three main blocks. The first block, competences in ICT use in searching for, and treatment of, information, consisted of 10 items on a 4-point Likert scale $(1=$ I feel totally incapable to $4=$ I feel totally in control). This block measured individual competence in the use of technological tools (e.g., "I know how to use programs to plan my study time"). The questionnaire was designed to gather the opinion of university students about the ability to work in digital skills. It has been used both in countries of the European Higher Education Area and in others, such as Mexico and Colombia (Conde, Trujillo, \& Castaño, 2017; Veytia, 2013).

This questionnaire was sent to the students at the three universities. The students were selected by nonprobability convenience sampling. The three universities were la Università degli Studi Suor Orsola Benincasa (Italy), Universidad Pablo de Olavide de Sevilla (Spain), and Spain's National Distance Education University (UNED). Data were collected during the 2017-2018 and 2018-2019 academic years. The questionnaires were distributed face to face in various subjects. The subjects were selected in different faculties to ensure the heterogeneity of the sample. For some incomplete questionnaires, the arithmetic mean of the variable in question was used as the imputation method. The questionnaire as a whole scored high in reliability (George \& Mallery, 2003) (Cronbach's $\alpha=.9, \omega=.75$ ), as did the subscale "competences in ICT use in searching for, and treatment of, information", (Cronbach's $\alpha=.91, \omega=.77$ ).

To study time distribution, 10 items were scaled: never (you never use it), hardly ever (less than 5 hours a week), and a lot (5 hours or more a week). The items were:

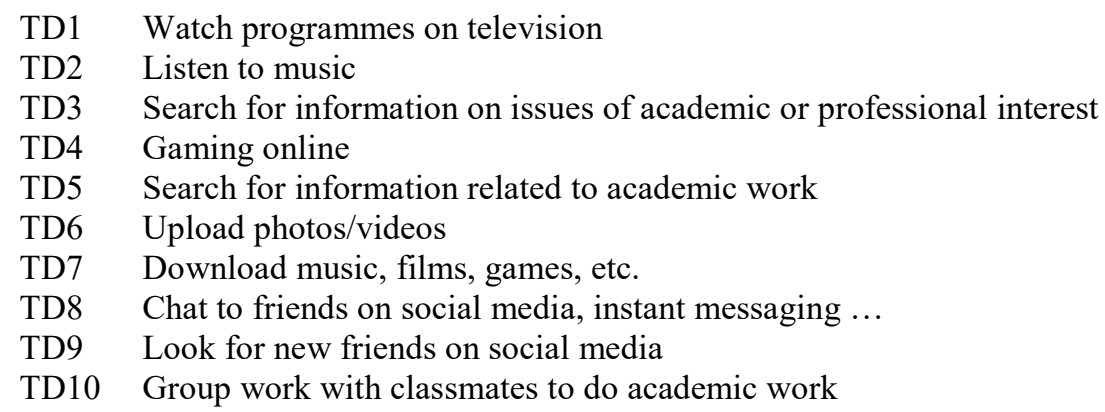

This study used 8 items to measure university students' digital competences in searching for, and treatment of, information. These items, on a 5-point Likert scale $(1=$ totally incapable of doing the task to 5 you believe you are totally in control), are detailed below, as well as how they relate to the areas of competence established by DigCom 2.1 (Carretero, Vuorikari, \& Punie, 2017).

DigCom 2.1. Competence Area 1: Information and data literacy. To articulate information needs. To search for and access data, information and content in digital environments, and to navigate between them. To create and update personal search strategies). Specific competences in the COBADI questionnaire:

CD1 I can surf the Internet using different search engines (Google, Mozilla, Opera, Explorer, etc.)

CD2 I can handle different search engines (research tools) (Ixquick, Mashpedia, Lexxe, etc.)

CD3 I can work the documents online (Google Drive, Skydrive, etc.)

Digcom 2.1. Competence Area 2: Communication and collaboration. To interact through a variety of digital technologies and to understand the appropriate digital communication means for a given context. Specific competences in the COBADI questionnaire:

CD4 I can organise, analyse and synthesise information with conceptual maps using social software tools (Cmaptool, Mindomo, Text2mindmap, Bubl, etc.) 
CD5 I can use programs to disseminate interactive presentations online (Prezi, SlideShare, Scribd, etc.)

Digcom 2.1. Competence Area 3: Digital content creation. To create and edit digital content in different formats, to express oneself through digital means. Specific competences in the COBADI questionnaire:

CD6 I can handle images using tools and/or social software apps (Gloster, Picmonkey, Animoto, etc.)

CD7 I feel capable of using postcasting and videocasts (flicks, odeo, YouTube, etc.)

CD8 I use QR codes to disseminate information

Finally, 4 items were used to study ICT use as a virtual and social communication tool in the university context; these were measured on a 5-point Likert scale $(1=$ totally incapable of doing the task to $5=y o u$ believe you are totally in control). These items were:

TIC1 I use the university's e-mail service

TIC2 I use the university's virtual learning platform

TIC3 I consult the university's online bulletin board

TIC4 I am active on the university's social networks

Data analysis examined multiple comparisons in the data's non-parametric correspondences. The data were analysed using SPSS v.22. Analysis of the time university students spent on the internet was done by multiple correspondence analysis, which is an extension of the simple correspondence analysis. The idea was to analyse the homogeneity of a set of $\mathrm{n}$ individuals described by more than two categorical variables. This method compares rows and columns, and then compares the rows and columns together, decomposing the chi-square measure of association into various components. Here the aim was to describe the relations between two nominal variables, set out in a table of correspondences, on a space containing few dimensions, and to describe the relations between the categories of each variable.

\section{Results}

This section presents the results of the investigation into the university students' basic digital competences. Table 1 shows some of the sample's descriptive statistics. The percentages of male and female students sampled at each university were similar, with the number of female students slightly higher. The mean ages of those surveyed at the Universidad Pablo de Olavide (UPO) and UNED were very similar, but slightly higher at Italy's Università degli Studi Suor Orsola Benincasa (USOB). In the latter case, the standard deviation value was also higher. The time students spent on the internet was first analysed as a whole by multiple correspondence analysis. Table 2 records the number of iterations required to reach the end solution. The procedure was halted at stage 25 due to the fact that the increase in the explained variance ceased to be significant enough to justify continuing the repetitions.

Table 1

Descriptive statistics from the sample

\begin{tabular}{|c|c|c|c|c|}
\hline \multirow{2}{*}{ University } & \multirow{2}{*}{ Sample } & \multicolumn{2}{|c|}{ Sex } & \multirow{2}{*}{ Median $(S D)$} \\
\hline & & Male & Female & \\
\hline $\begin{array}{l}\text { Università degli Studi Suor } \\
\text { Orsola Benincasa (Italy) }\end{array}$ & 103 & $26(25.2 \%)$ & $77(74.8 \%)$ & $25.23(7.98)$ \\
\hline $\begin{array}{l}\text { Universidad Pablo de Olavide } \\
\text { (Spain) }\end{array}$ & 644 & $66(10.2 \%)$ & $578(89.8 \%)$ & $20.55(4.71)$ \\
\hline UNED (Spain) & 326 & $58(17.8 \%)$ & $268(82.2 \%)$ & $22.48(3.70)$ \\
\hline
\end{tabular}

Table 2 presents a summary of the model. Two dimensions were created. The eigenvalue reveals the proportion of information in the model explained by each dimension, in other words, it enables the importance of each dimension to be analysed, with the first dimension observed as being more important than the second. Table 2 also shows each dimension's inertia and explained variance percentage. Total inertia refers to the mean of the distances of each point's square to the gravitational centre of the point cloud. The first dimension explained more of the inertia $(23.66 \%)$ than the second $(15.18 \%)$. Overall, the two dimensions explained $38.84 \%$ of the total inertia, and the first dimension has greater correlation. 
Table 2

Model summary

\begin{tabular}{lrrr}
\hline Dimension & Cronbach's alpha & \multicolumn{3}{c}{ Variance accounted for: } \\
& & Total & $\%$ \\
\hline 1 & 0.642 & 2.366 & 23.66 \\
2 & 0.379 & 1.518 & 15.18 \\
\hline Total & & 3.884 & \\
Mean & 0.539 & 1.942 & 19.42 \\
\hline
\end{tabular}

Table 3 presents the coordinates for each variable of each category in the two dimensions. This information shows the position of each category and how it is related to each dimension. The highest coordinates show that the category is associated with the corresponding dimension, since the further away they are from the origin, the stronger the relation to the dimension. This table also shows the response hardly ever in the "watch programmes on television" variable was more closely related to Dimension 1 than 2 , since the coordinates were 0.672 and -0.257 , respectively. However, for the never response of this same variable, the difference was not so great given that the coordinates were -0.154 and 0.053 .

Table 3

Coordinates of each variable's categories

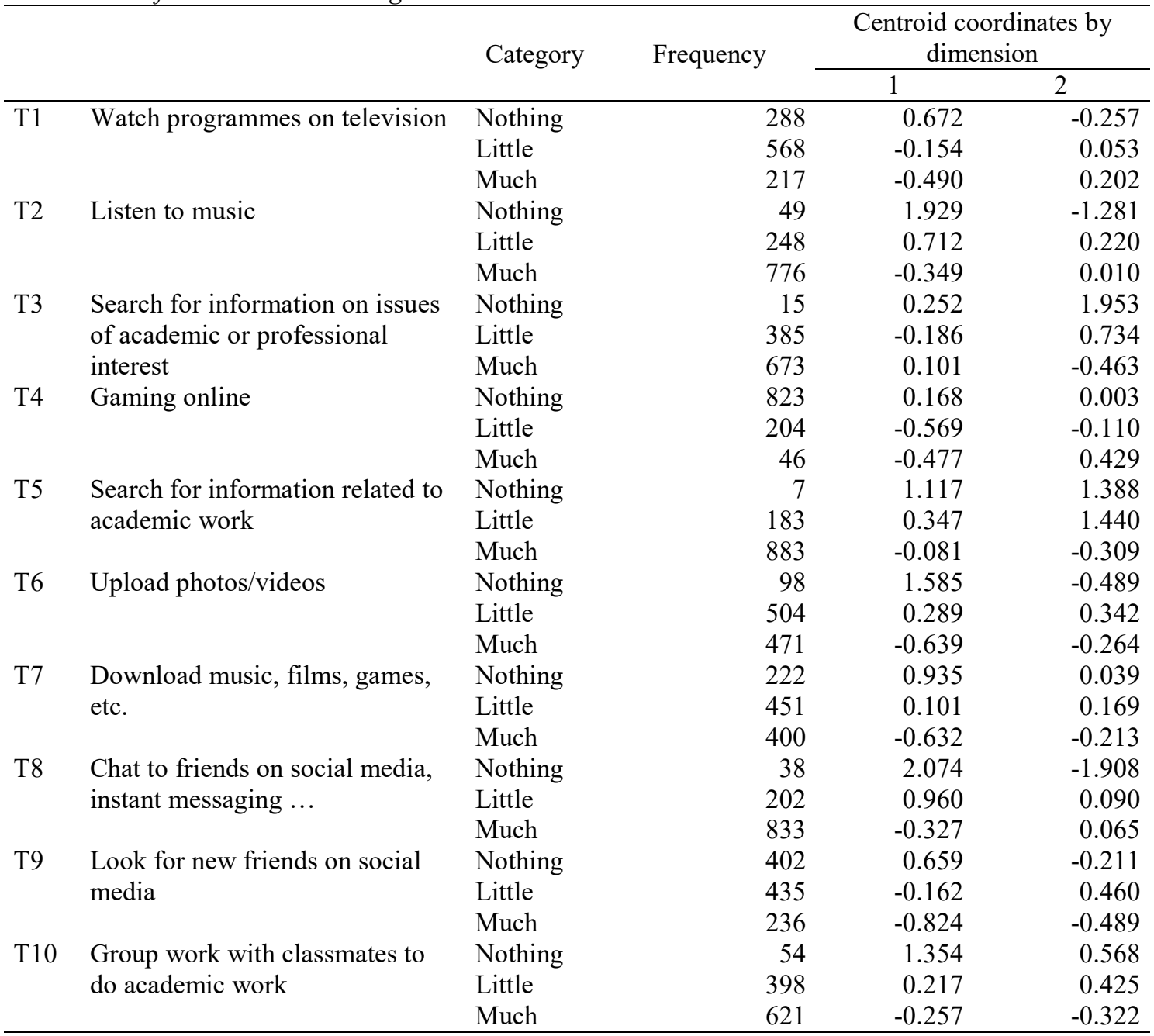

Figure 1 identifies student profiles according to the time spent on the internet engaging in various activities. Figure 1 can be interpreted according to the proximity between categories in terms of their similarity, that is, two categories are close to each other because, overall, the individuals are similar. As previously mentioned, dimension 1 had a greater inertia than dimension $2(23.66 \%$ vs. $15.18 \%)$. This implies that the 
explanatory nature of the first dimension was greater than the second. We can see that on the left side of dimension 1, we will find the much level of variables: "Look for new friends on social media", "Upload photos/videos", "Download music, films, games, etc.", and "Gaming online" (this last variable in the little category). In this left part there is also the much level of variables of academic subjects. On the contrary, at the opposite pole of this dimension is the level nothing of the variables: "Listen to music" and "Chat to friends on social media, instant messaging ...", and "Upload photos/videos". Therefore, this dimension provides us with information on social relations and leisure, since it includes individuals who have strong levels of social relations and leisure compared to those who do not, although in a way it also discriminates against those individuals who spend a lot of time in academic issues compared to those who barely spend time on leisure and social relations issues. If we focus on the second dimension, which is less explanatory, we can see that those individuals who have the nothing-medium level were located in the variables: "Issues of academic or professional interest" and "Search for information related to academic work." On the contrary, at the opposite pole we can locate the level nothing of the variables: "Listen to music" and "Chat to friends on social media, instant messaging ...". Therefore, this variable could be providing information on individuals who used little information for both academic and leisure tasks. Finally, in Figure 1, we can observe that the level $a$ lot of the points associated with variables on academic subjects as well as variables on social relations and leisure topics was very close, which means that there was a profile of individuals who used $a$ lot time in both tasks.

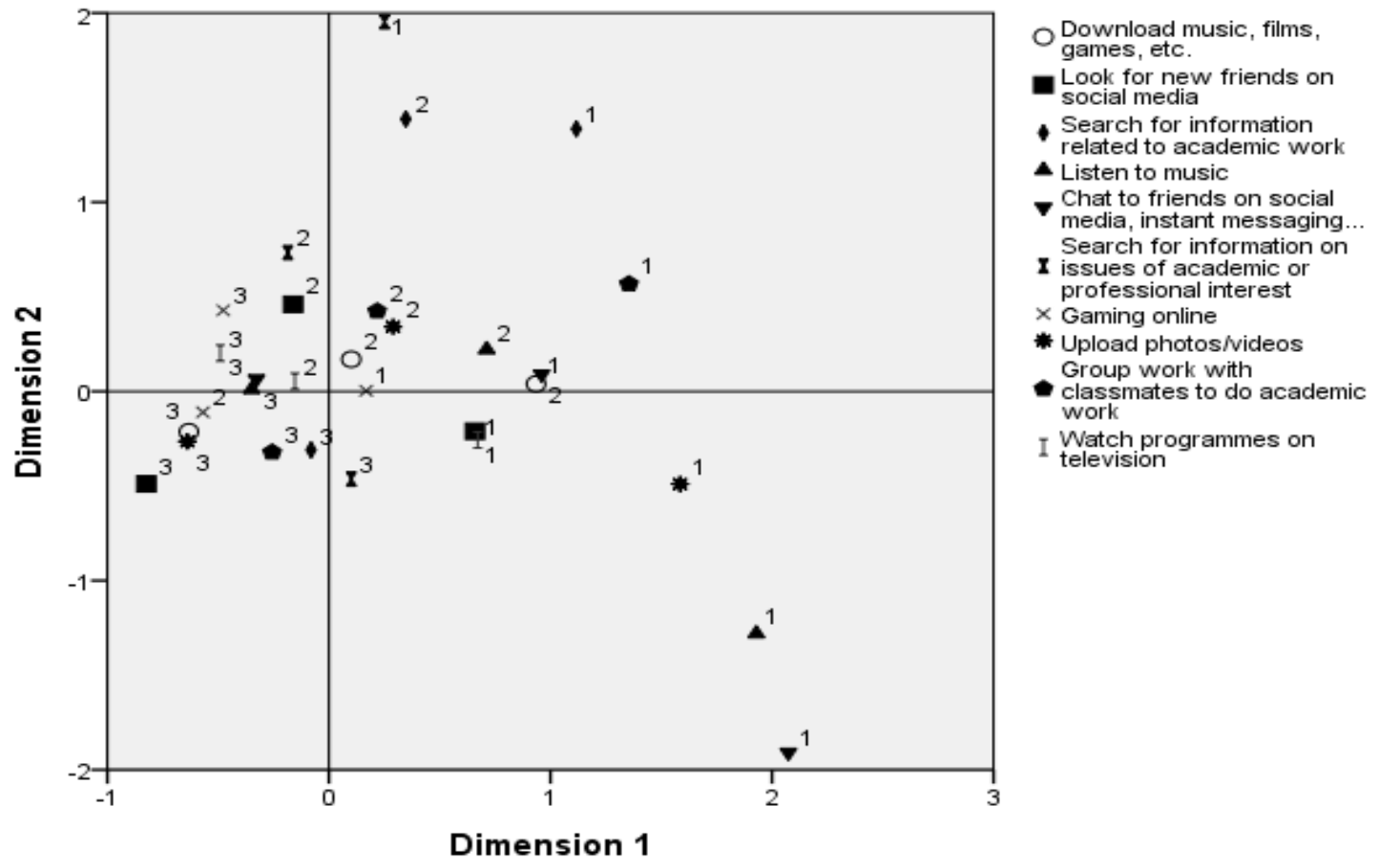

Figure 1. Combined graph showing category points

Table 4 shows how far each variable discriminated in each dimension. Dimension 1 was mainly explained by the variables: "Upload photos/videos", "Chat to friends on social media, instant messaging...," "Listen to music", and "Download music, films, games, etc." On the other hand, Dimension 2 was mainly explained by the variables of "Search for information on issues of academic or professional interest" and for "Information related do academic work". Therefore, we can state the first dimension was clearly associated to leisure activities, while the second related to academic work. This is evident in Figure 2. However, it should be considered that the explanatory capacity of the first axis was superior to that of the second. Currently, reliable information sources such as Google or Wikipedia are extremely useful for data searching and resolving academic questions. Access to the internet means that students do not have to go to a library to find information, as online searching puts within any student's reach the images, text, and scientific documents, that can be applied to a vast array of knowledge areas. 
Table 4

Discriminant measures

\begin{tabular}{|c|c|c|c|c|}
\hline \multirow[t]{2}{*}{ Variables } & & \multicolumn{2}{|c|}{ Dimension } & \multirow[t]{2}{*}{ Mean } \\
\hline & & 1 & 2 & \\
\hline $\mathrm{T} 1$ & Watch programmes on television & 0.182 & 0.027 & 0.105 \\
\hline $\mathrm{T} 2$ & Listen to music & 0.375 & 0.086 & 0.231 \\
\hline $\mathrm{T} 3$ & $\begin{array}{l}\text { Search for information on issues of academic or } \\
\text { professional interest }\end{array}$ & 0.020 & 0.381 & 0.200 \\
\hline $\mathrm{T} 4$ & Gaming online & 0.093 & 0.010 & 0.052 \\
\hline $\mathrm{T} 5$ & Search for information related to academic work & 0.034 & 0.445 & 0.239 \\
\hline T6 & Upload photos/videos & 0.448 & 0.108 & 0.278 \\
\hline $\mathrm{T} 7$ & Download music, films, games, etc. & 0.334 & 0.029 & 0.182 \\
\hline T8 & Chat to friends on social media, instant messaging ... & 0.409 & 0.134 & 0.271 \\
\hline T9 & Look for new friends on social media & 0.323 & 0.155 & 0.239 \\
\hline $\mathrm{T} 10$ & Group work with classmates to do academic work & 0.148 & 0.143 & 0.146 \\
\hline Total & & 2.366 & 1.518 & 1.942 \\
\hline Percenta & nce explained & 23.661 & 15.184 & 19.422 \\
\hline
\end{tabular}

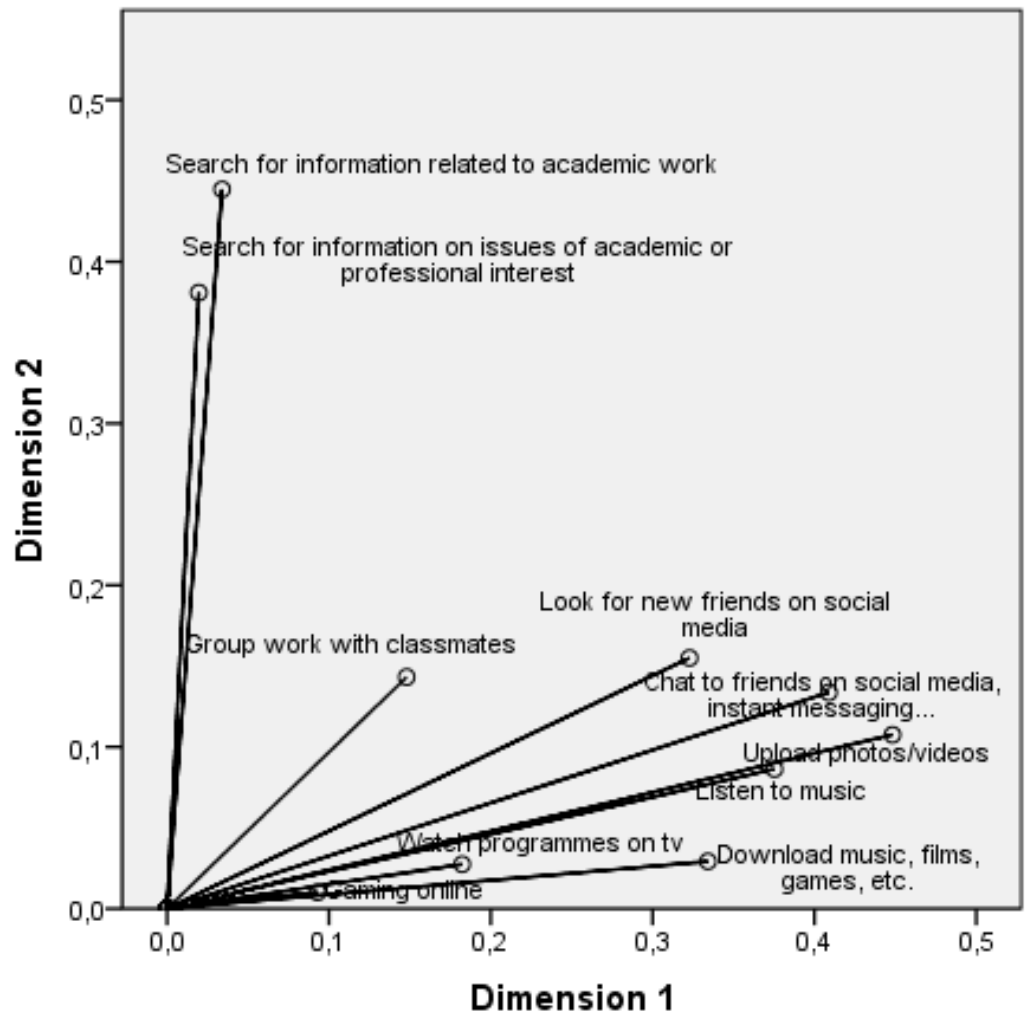

Figure 2. Discriminant measures

The structure of students surveyed at the Universidad Pablo de Olavide (UPO) and the UNED was very similar. There was a group of students who spent most of their time on the internet downloading music, listening to music, uploading photos/videos and chatting to friends on social media, whereas another group spent most of its online time searching for information related to academic work and looking for information on academic and professional issues. It is worthy of note that the variable "Information on issues of academic or professional interest" was important at the UPO and UNED but not at the USOB. This could be due to the fact that those surveyed at the Italian university were older than students attending the Spanish universities and might already be employed, thus the need to seek out information of an academic and professional nature was less intense. It is also noteworthy that at the USOB the "Gaming online" variable was far more important than at the two Spanish universities, where it scarcely registered. 
On completing an overall analysis of the data, it was interesting to see whether there were any significant differences in the activities to which the undergraduates dedicated time on the internet with regard to the three universities. To avoid distorting the analysis, only discriminant measures were added for each university (Figures 3-5). The students attending the Università degli Studi Suor Orsola Benincasa (USOB) spent most of their time on the internet downloading music, films and games, and seeking out new friendships on social media, and to a lesser extent uploading photos/videos and working with groups of colleagues to do academic work.

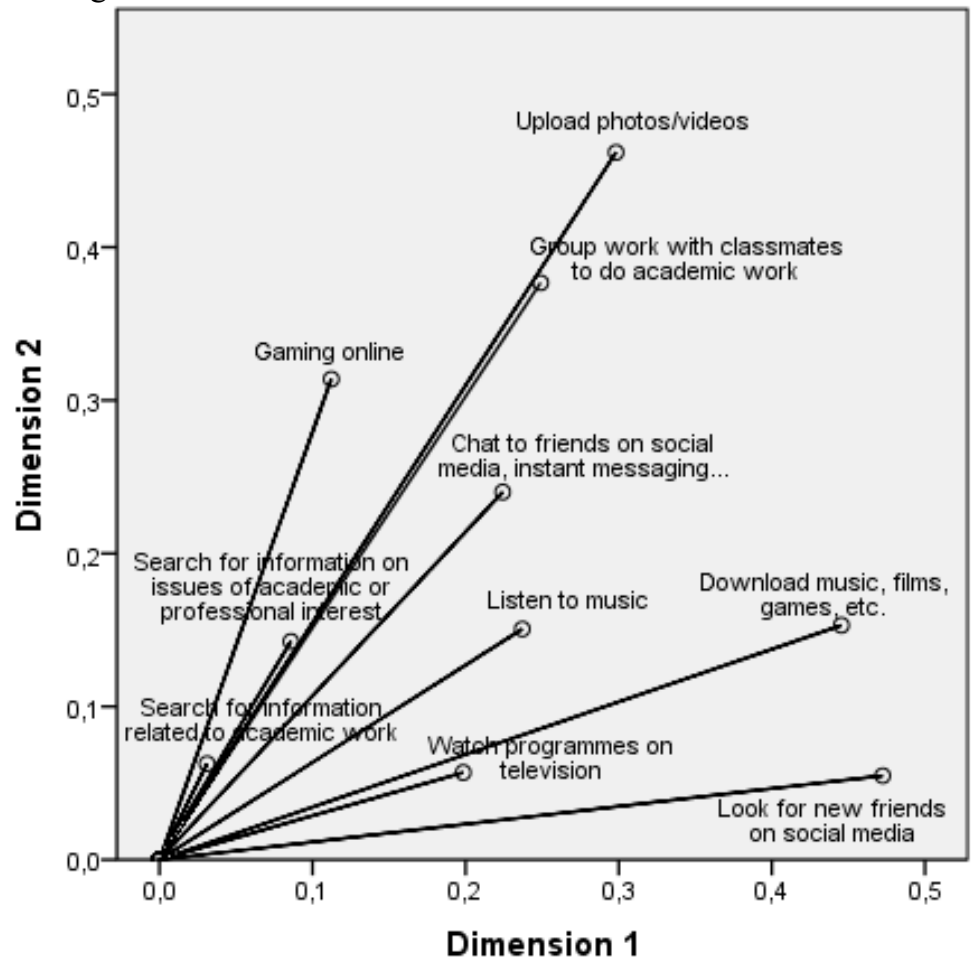

Figure 3. Discriminant measures by university (Università Benincasa)

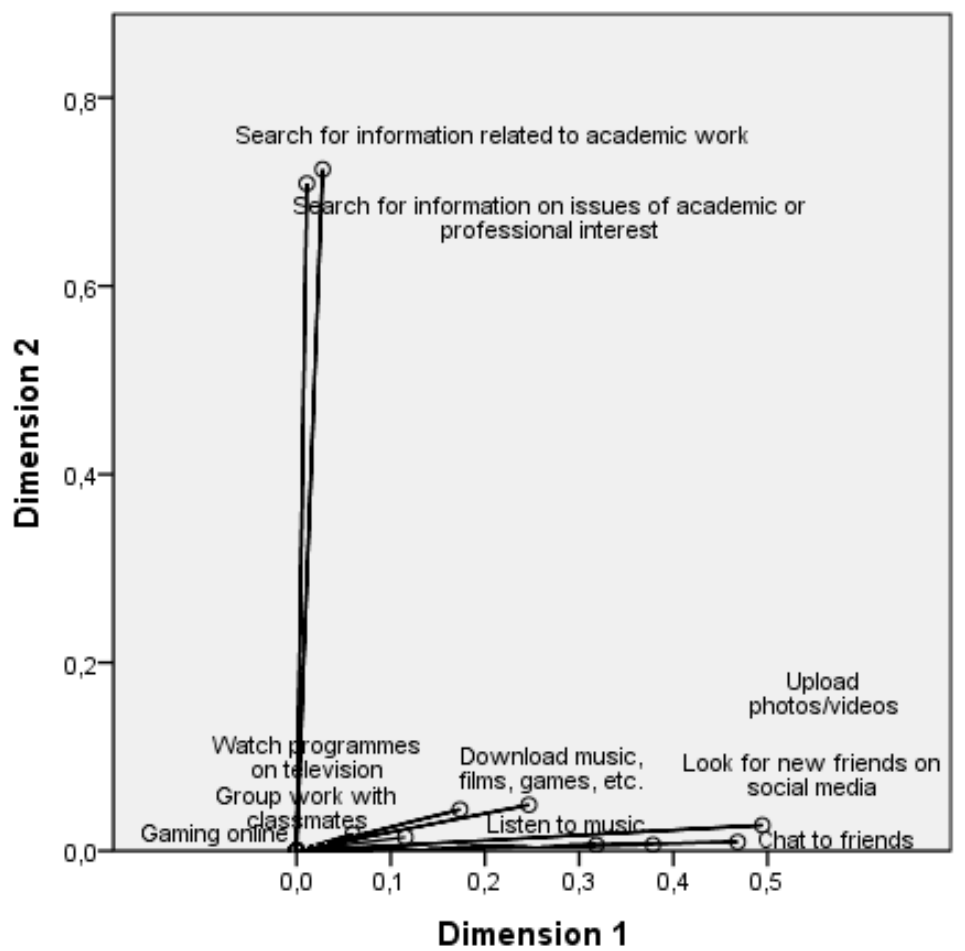

Figure 4. Discriminant measures by university (Universidad Pablo de Olavide) 


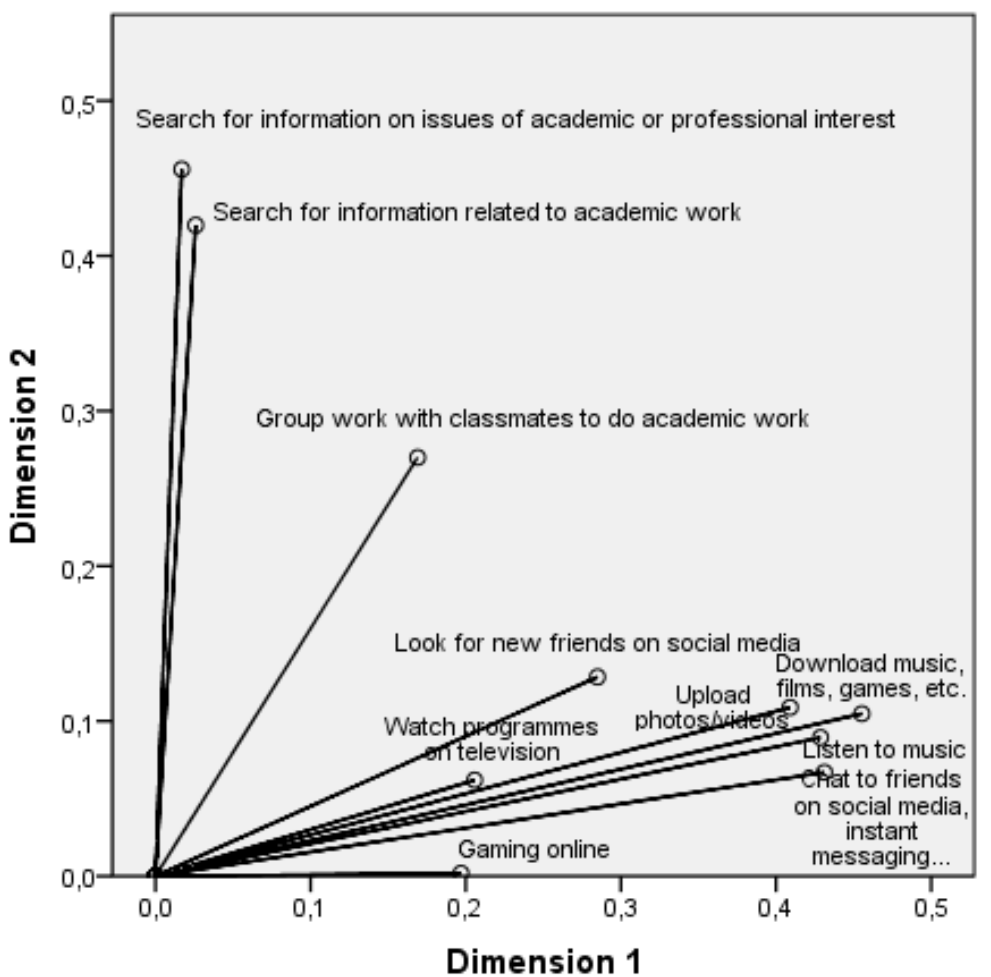

Figure 5. Discriminant measures by university (UNED)

Another research objective in this work was to analyse university students' digital competences in searching for, and treatment of, information. Figure 6 shows the mean proportional scores for the students for each of the factors analysed.

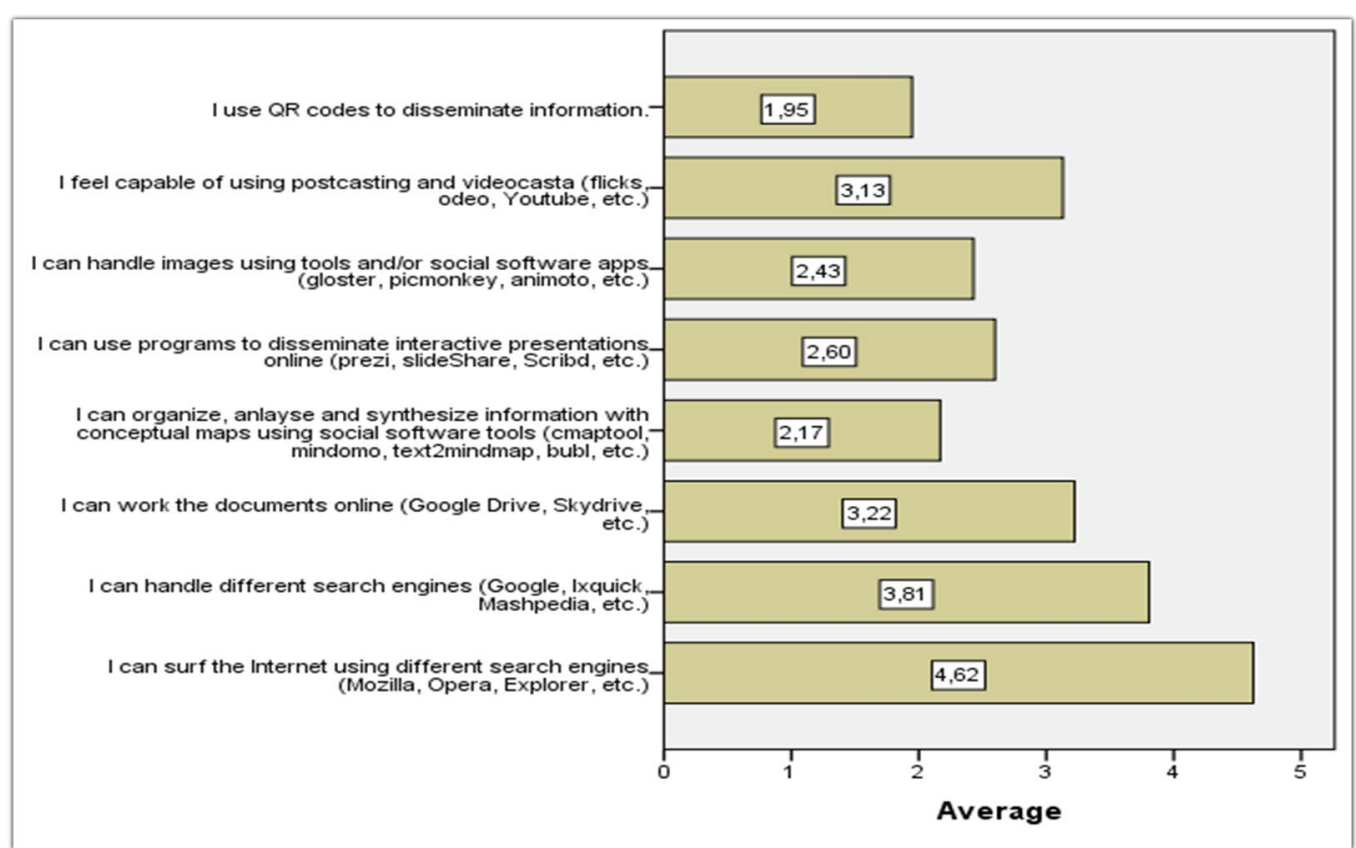

Figure 6. Digital competences in information searching and treatment

It can be seen how the majority of students were able to use various search engines and work with documents online via Google Drive and Skydrive for example. By contrast, students made little use of QR code to disseminate information or conceptual maps with the use of social software tool. Currently, the 
educational use of QR codes is a limited resource because its employment is not widespread, although QR codes in classrooms have been identified as an important tool in promoting active as well as distributed learning, especially in higher education (Abdul Rabu, Hussin, \& Bervell, 2019; Ali, Santos, \& Areepattamannil, 2017). In some cases, the use of QR enables new teaching models and greater student participation in teaching-learning activities as a predictor of skills development (Pérez-Sanagustín, Parra, Verdugo, García-Galleguillos, \& Nussbaum, 2016).

The Kruskal-Wallis test was used to compare the three universities in terms of students' digital competences, given the non-normality in the variables. The results are presented in Table 5. There were significant differences to a level of significance of 5\% in all the variables, except in digital competence CD5, which refers to the use of programs to disseminate interactive presentations online. Thus, apart from this digital competence, there were differences in all competences between the universities studied. In other words, the level of student efficacy in digital competences varied significantly between the three higher education institutions.

Table 5

The Kruskal-Wallis test for differences between the universities for students' digital competences

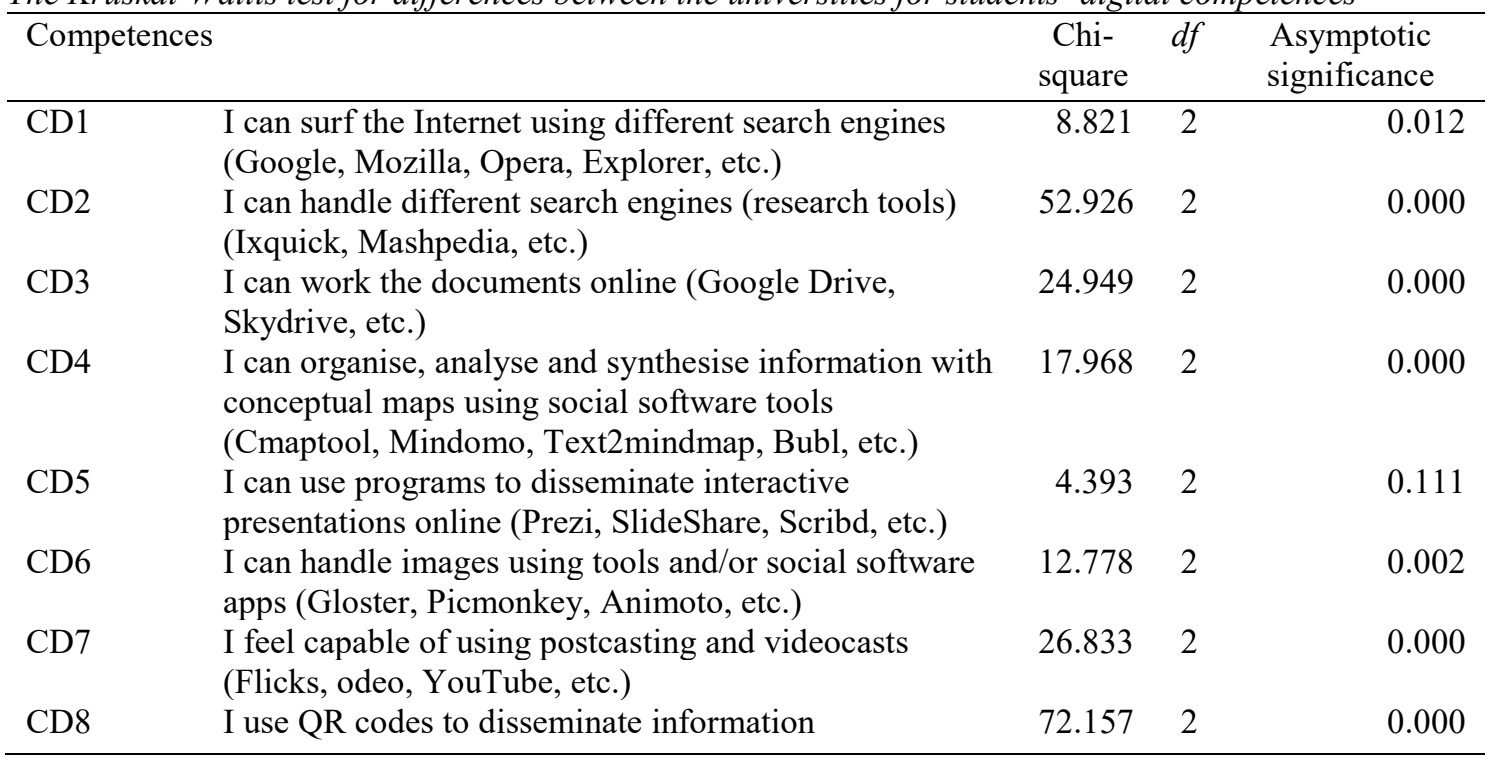

Finally, another objective of this research was to study ICT use at university as a virtual and social communication tool. Four variables were used. Our study also analysed the potential for significant differences in ICT use. Figure 7 presents the mean scores for each variable on a 5-point Likert scale $(1=$ totally incapable of performing the task to $5=$ you believe you are totally in control). The findings showed that the virtual university platform was the ICT most widely used by the students surveyed. This underlines the institutions' commitment to digitalising education. In contrast, the universities' social media platform was cited as the least used ICT. 


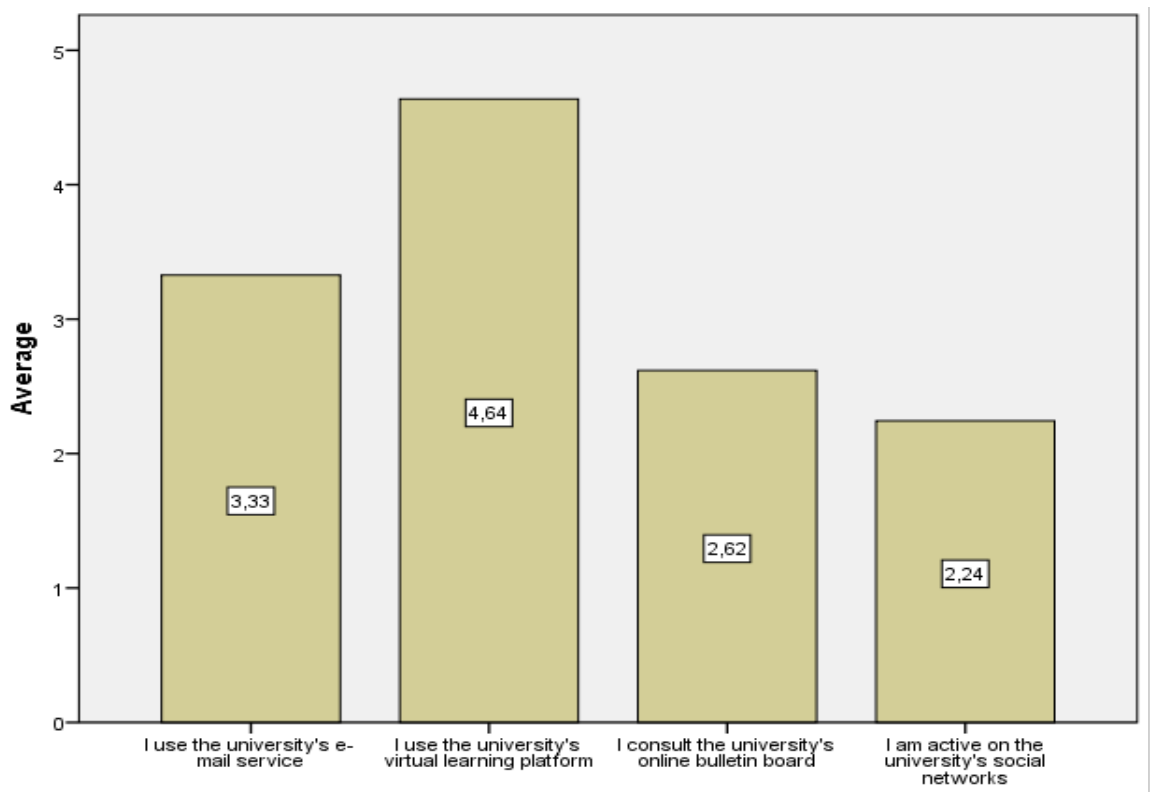

Figure 7. ICT use in the university context

Table 6 shows the Kruskal-Wallis test for differences in the variables applied to the university context studied. It can be inferred that there were significant differences in three of the four variables, the exception being the use of the virtual university platform. The extent of use of this platform in each of the three universities was similar.

Table 6

Kruskal-Wallis test for differences in ICT use in the university context

\begin{tabular}{llrrr} 
& & Chi-square & $d f$ & $\begin{array}{c}\text { Asymptotic } \\
\text { significance }\end{array}$ \\
\hline TIC1 & I use the university's e-mail service & 77.793 & 2 & 0.000 \\
TIC2 & I use the university's virtual learning platform & 1.416 & 2 & 0.493 \\
TIC3 & I consult the university's online bulletin board & 78.665 & 2 & 0.000 \\
TIC4 & I am active on the university's social networks & 77.460 & 2 & 0.000 \\
\hline
\end{tabular}

These differences can be observed in the graph from the analysis in Figure 8, which highlights that e-mail use was more intense at the USOB, followed by UNED, and UPO. Consultation of the online university bulletin board was similar at UNED and UPO, but less frequent than at USOB. Social network use was most intense at USOB, followed by UNED and UPO. Thus, it can be inferred that although the ICT structure as similar at the three universities, intensity of use varied. 


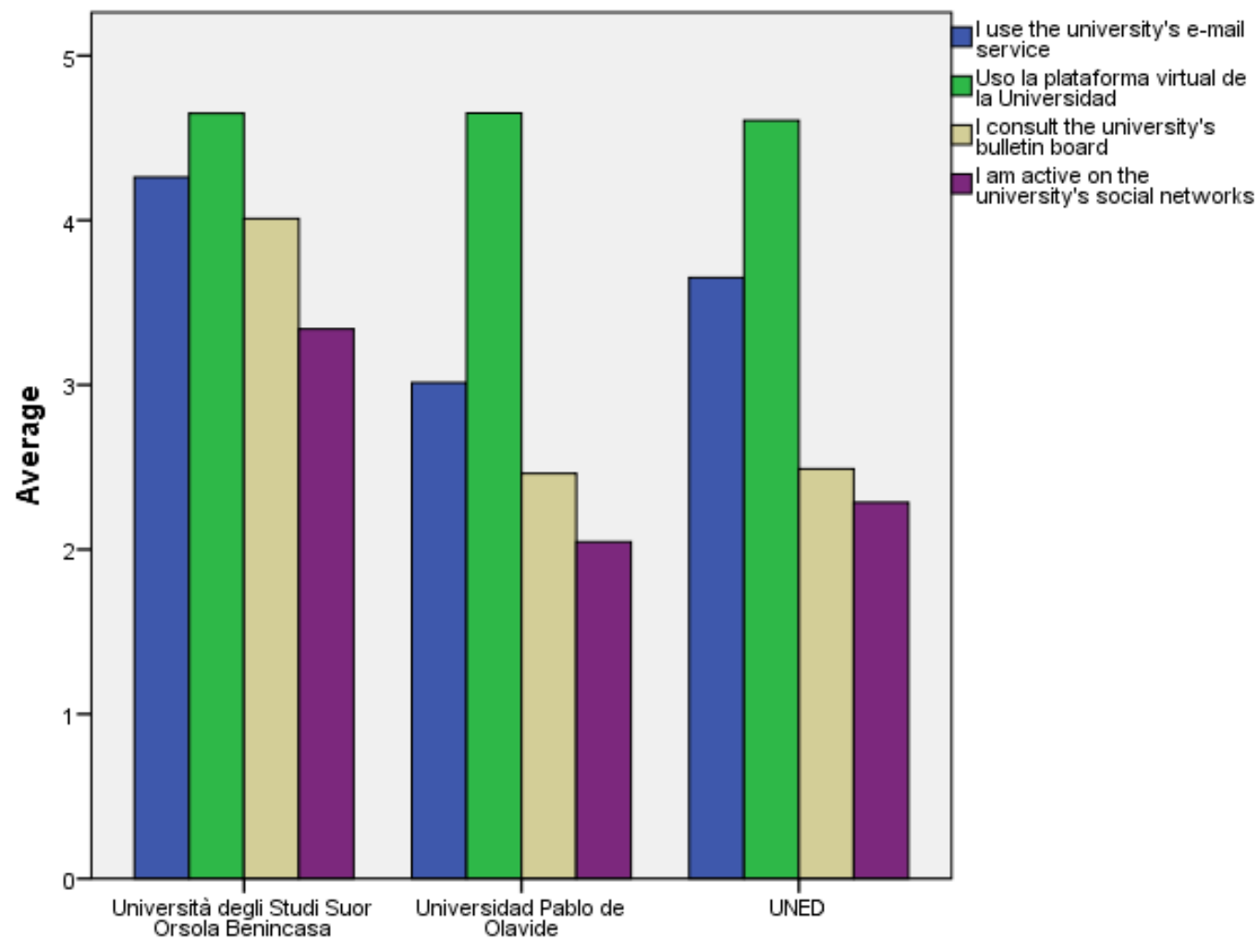

Figure 8. Mean scores for ICT use between the three universities

\section{Discussion and conclusion}

Today's society requires its citizens to be trained in digital competences and its students to be able to use technology on a functional level and in a way that boosts their academic, personal, and professional prospects (European Commission, 2018; Warschauer, 1999). The results show that two university student profiles could be inferred for time spent on the internet. Firstly, those students who spent most of their time online pursuing leisure activities. This student type has a greater online social presence, and this allows them to develop a more active and cohesive form of communication in group and collaborative learning processes (Armellini \& De Stefani, 2015; Dickie \& Meier, 2015; Ellefsen, 2015; Garrison, 2011; Wang, Woo, Quek, Yang, \& Liu, 2012). Secondly, those students who spent hardly any time on the internet searching for information or doing academic work, and who used the internet mainly for leisure and entertainment (Sharma \& Shukla, 2016; Sultan \& Christian, 2014; Valkenburg, Peter, \& Schouten, 2006). These findings link with studies on internet use that propose this could have a positive effect on students' academic performance (Gil-Flores, 2009), and with other studies which, as indicated by Torres-Díaz, Duart, Gómez-Alvarado, Marín-Gutiérrez, \& Segarra-Faggioni (2016), point to the opposite effect (Chen \& Fu, 2009; Raines, 2012; Suhail \& Bargees, 2006).

Both groups had an acceptable level of competence in areas 1 and 2: "Area 1. Information and data literacy", and "Area 2. Communication and collaboration". Today, activities such as uploading photos and contact with friends through social media are booming among university undergraduates, especially on Instagram or Facebook. As (Alhabash \& Ma, 2017, p. 3) establish: "people use social media to obtain information about others". The information gained helps them maintain interpersonal relationships, as depicted by Seidman (2013), thus helping them fulfil their need to belong (Baumeister \& Leary, 1995). In this sense, Joinson (2008) identified seven motivations for Facebook use among college students: social connection, shared identities, photographs, content, social investigation, social network surfing, and status updates. Other studies show that the university student uses more Facebook as an academic tool, to connect with student groups, or to search information (Alhabash, Chiang, \& Huang, 2014; Karlis, 2013) and Instagram for exhibitionism, interpersonal connectivity, and voyeurism (Mäntymäki \& Islam, 2016; Stanley, 2015). 
In addition, there are numerous platforms that enable music and films to be downloaded, which encourages student involvement in this type of activity. This entertainment-related use of the internet can have a positive effect on academic performance (Mishra, Draus, Goreva, Leone, \& Caputo, 2014; Torres-Diaz, et al. 2016; Türel \& Toraman, 2015). "Students who use Internet extensively for entertainment tend to fail fewer subjects than students who use Internet at all, or very little" (Torres-Diaz et al. 2016, p. 68). In this sense, Matzat and Vrieling (2015) show that:

[E]arlier studies (Ahn, 2011; Junco, 2012; Junco, Elavsky, \& Heiberger, 2013; Mazer, Murphy, \& Simonds, 2009) indicate that the (desirable or undesirable) effects of social media integration strongly depend on the way students use them and that some outcomes can be influenced by the interference of the teacher. (p. 74)

Likewise, the use of social networks could substantially improve student socialisation and collaboration in the development of social competences and interaction in the study (Sushma, Peter, Natalya, Gregory, \& Donald, 2014). The results from our investigation fit with other studies that show that those students who prefer to use the internet to search for information because they can access a wider range of information sources and know the context within which that information is created, are better achievers academically (Blayone, et al. 2017; Leung \& Lee, 2012; Torres-Diaz et al., 2016).

Likewise, the development of competences is closely related to different cognitive areas, and the frequent use of technology seems to have positive effects on spatial skills, processing, memory improvement, and communication skills. The meta-analysis of Heyam (2014) shows that the use of technology and social networks improves communication, socialisation, coordination, collaboration, and entertainment processes, although a pronounced use can cause addiction, social isolation, and waste of time. In the most passive role in social networks (due to lack of knowledge, competence, or low income that prevents its use) the negative effect on academic performance is greater. The research of Torres-Diaz et al. (2016,) shows that:

[T]he students who download files and use the Internet extensively for entertainment purposes tend to fail fewer subjects than those who do not use the Internet, or rarely use it, for entertainment but this runs contrary to several studies (Frangos, Frangos, \& Kiohos, 2010; Mishra et al., 2014; Türel \& Toraman, 2015). (p. 67)

Likewise, the design of the subjects could also integrate didactically the use of social networks to favour new learning environments. For example, as Zachos, Paraskevopoulou-Kollia, and Anagnostopoulos (2018) established in their review of social media use in higher education: "we reviewed studies that revealed the positive impact of online social networks' on education processes, and mainly on higher education" (p. 2). They collected 77 articles from 2010 onwards, where Facebook and Twitter were the basic platforms for educational purposes. This kind of learning that can be called informal and that is facilitated by the interaction and personal use of social networks can be an advance to favour self-regulated learning (Dabbagh, \& Kitsantas, 2012; Matzat, \& Sadowski, 2012).

On the other hand, both groups of students' competence level in area 3, "digital content creation", was lower intermediate, especially in the ability to create multimedia content with a range of tools. Based on the concepts of Gil-Flores, Rodríguez-Santero, \& Torres-Gordillo (2017) and Tondeur et al. (2017), one of the fundamental digital competency components is being able to create digital information and media. In all geographical contexts (America, Europe, Asia) creation is one of the basic components (American Library Association, 2013; Association of Southeast Asian Nations (ASEAN), 2018; European Commission, 2019). This also requires a competency model design of the subjects with the practical inclusion of activities mediated by technology to guarantee sufficient adequacy between the academic world and the labour market. As Torres-Coronas and Vidal-Blanco (2014) point out:

[I]n a situation of contracting and extremely competitive labour markets, confirmation of the fit between the profile required by the market and the profile achieved during the training process becomes particularly important. (p.65) 
Thompson (2013) established:

[D]igital natives use a narrow range of digital technologies' such as "the smartphone for making calls and messaging", "social networks", "instant messaging using the computer", "web searching", "watching videos online", "listening to music online", and they do not use many other technologies that are often cited as potentially educational [...] such as blogs or games. (p. 20)

The development of digital skills is crucial so that the university student can perform an adequate professional and academic performance and deepen the educational and professional use of digital tools. For learning on the web and the use of digital devices to be a deeper and more significant experience requires that students themselves gather, organise, analyse and create their own knowledge (Deschryver \& Spiro, 2008, p. 4).

\section{Limitations and further research}

Although the results of this study were derived from a robust quantitative analysis, there are some limitations. In the first place, the quantitative analysis should be complemented with a qualitative analysis with open questions that will allow more in-depth results on the type of activities carried out on the internet, the degree of competence derived from some of these activities, and their impact on the development of academic competences. Likewise, the relationship between the connection time and the academic performance of the students should be analysed in greater depth since there are several studies that have found positive effects on the academic performance and the improvement of the digital skills while in others there is no evidence of that improvement (Chen \& Fu, 2009; Hunley, Evans, Delgado-Hachey, Krise, Rich, \& Schell, 2005; Raines, 2012; Suhail \& Bargees, 2006). Another limitation is not having analysed the use of social networks, such as Instragram, and their relationship with the development of skills and academic performance of students. This analysis could explain certain student behaviours in social networks. Ultimately, there are difficulties to overcome, such as the question of privacy in communications, teacher training, investment in technological infrastructure, and updating to a more advanced techno-didactic approach that connects the reality of current social and professional life with society today.

\section{Acknowledgements}

This study originated in the directive established in the Innovation in Education with ICT 2.0 in the European Higher Education Space, developed within the framework of the Innovation and Development in Education projects organised by the Universidad Pablo de Olavide de Sevilla, and financed by that university's Vice-Rectorate for Education and European Convergence, and with the support of members of the EduInnovagogía ${ }^{\circledR}$ (HUM-971) research group. This group is recognised by the Andalusian Plan for Research, Development and Innovation, and the Research Results Transfer Office at the UPO.

\section{References}

Abdul Rabu, S. N., Hussin, H., \& Bervell, B. (2019). QR code utilization in a large classroom: Higher education students' initial perceptions. Education and Information Technologies, 24(1), 359, 384. https://doi.org/10.1007/s10639-018-9779-2

Ahn, J. (2011). The effect of social network sites on adolescents' social and academic development: Current theories and controversies. Journal of the American Society for Information Science and Technology, 62(8), 1435-1445. https://doi.org/10.1002/asi.21540

Alhabash, S., Chiang, Y. H., \& Huang, K. (2014). MAM \& U\&G in Taiwan: Differences in the uses and gratifications of Facebook as a function of motivational reactivity. Computers in Human Behavior, 35, 423-430. https://doi.org/10.1016/j.chb.2014.03.033

Alhabash, S., \& Ma, M. (2017). A tale of four platforms: Motivations and uses of Facebook, Twitter, Instagram, and Snapchat among college students? Social Media + Society, 3(1), 1-13. https://doi.org/10.1177/2056305117691544

Ali, N., Santos, I. M., \& Areepattamannil, S. (2017). Pre-service teachers' perception of quick response (QR) code integration in classroom activities. The Turkish Online Journal of Educational Technology, 16(1), 93-100. 
American Library Association (2013). Digital competencies. Libraries, and public policy: Report of the Office for Information Technology Policy's digital competencies task force. Retrieved from http://www.districtdispatch.org/wp-content/uploads/2013/01/2012_OITP digilitreport_1_22 13.pdf

Armellini, A., \& De Stefani, M. (2015). Social presence in the 21 st century: An adjustment to the community of inquiry framework. British Journal of Educational Technology, 47(6), 1202-1216. https://doi.org/10.1111/bjet.12302

Association of Southeast Asian Nations (2018). ASEAN ICT-Digital Standards Competences. Retrieved from https://www.cfr.org/backgrounder/asean-association-southeast-asian-nations

Bancroft, J. (2016). Multiliteracy centers spanning the digital divide: Providing a full spectrum of support. Computers and Composition, 41(3), 46-55. https://doi.org/10.1016/j.compcom.2016.04.002

Barber, W., DiGiuseppe, M., vanOostveen, R., Blayone, T., \& Koroluk, J. (2016, November). Examining student and educator use of digital technology in an online world. Paper presented at the Second International Symposium on Higher Education in Transformation, Ontario Tech University, Oshawa.

Barlow-Jones, G., \& van der Westhuizen, D. (2011). Situating the student: Factors contributing to success in an information technology course. Educational Studies, 37(3), 303-320. https://doi.org/10.1080/03055698.2010.506329

Baumeister, R. F., \& Leary, M. R. (1995). The need to belong: Desire for interpersonal attachments as a fundamental human motivation. Psychological lulletin, 117(3), 497-529.

Bawden, D. (2008). Origins and concepts of digital Literacy. In C. Lankshear, \& M. Knobel (Eds.), Digital literacies: Concepts, policies and practices (pp. 17-32). New York, NY: Peter Lang.

Bendermacher, G. W. G., Oude Egbrink, M. G. A., Wolfhagen, I. H. A. P., \& Dolmans, D. H. J. M. (2017). Unravelling quality culture in higher education: A realist review. Higher Education, 73(1), 3960. https://doi.org/10.1007/s10734-015-9979-2

Bennett, L. (2014). Learning from the early adopters: Developing the digital practitioner. Research in Learning Technology, 22, 21453-21466. https://doi.org/10.3402/rlt.v22.21453

Bhuasiri, W., Xaymoungkhoun, O., Zo, H., Jeung, J., \& Ciganek, A. (2012). Critical success factors for elearning in developing countries: A comparative analysis between ICT experts and faculty. Computers \& Education, 58(2), 843-855. https://doi.org/10.1016/j.compedu.2011.10.010

Blas Padilla, D., Vázquez-Cano, E., Morales Cevallos, M., \& López-Meneses, E. (2019). Use of augmented reality apps in University classrooms. Campus virtuales, 8(1), 37-48.

Blayone, T., Mykhailenko, O., VanOostveen, R., Grebeshkov, O., Hrebeshkova, O., \& Vostryakov, O. (2017). Surveying digital competencies of university students and professors in Ukraine for fully online collaborative learning. Technology, Pedagogy and Education, 27(3), 1-18. https://doi.org/10.1080/1475939X.2017.1391871

Brečko, B., Ferrari, A. (2016). In R. Vuorikari, \& Y. Punie (Eds.). The Digital Competence Framework for consumers. Joint Research Centre Science for Policy Report. EUR 28133 EN. Luxembourg: Publications Office of the European Union. https:/doi.org/10.2791/838886

Buchanan, T., Sainter, P., \& Saunders, G. (2013). Factors affecting faculty use of learning technologies: Implications for models of technology adoption. Journal of Computing in Higher Education, 25(1), 111. https://doi.org/10.1007/s12528-013-9066-6

Cabero, J., Vázquez-Cano, E., \& López-Meneses, E. (2018). Use of augmented reality technology as a didactic resource in university teaching. Formación Universitaria, 11(1), 25-34. https://doi.org/http://dx.doi.org/10.4067/S0718-50062018000100025

Carretero, S., Vuorikari, R., \& Punie, Y. (2017). DigComp 2.1: The Digital Competence Framework for Citizens with eight proficiency levels and examples of use. Publications Office of the European Union. Luxemburg. https://doi.org/10.2760/38842

Chen, S. Y., \& Fu, Y. C. (2009). Internet use and academic achievement: Gender differences in early adolescence. Adolecense, 44(176), 797-812.

Conde, E., Trujillo, J. J., \& Castaño, H. (2017). Deciphering the curriculum through ICT: An interactive vision on the digital competences of students of sports science and physical activity. Revista de Humanidades, 31(10), 159-214. https://doi.org/10.5944/rdh.31.2017.19079

Cronin, C. (2017). Openness and praxis: Exploring the use of open educational practices in higher education. The International Review of Research in Open and Distributed Learning, 18(5), 15-34. https://doi.org/10.19173/irrodl.v18i5.3096

Dabbagh, N., \& Kitsantas, A. (2012). Personal learning environments, social media, and self-regulated learning: A natural formula for connecting formal and informal learning. Internet and Higher Education, 15(1), 3-8. https://doi.org/10.1016/j.iheduc.2011.06.002 
Daniel, J., Vázquez-Cano, E., \& Gisbert, M. (2015). The future of MOOCs: Adaptative learning or business model? Universities and Knowledge Society Journal, 12(1), 64-73.

https://doi.org/10.7238/rusc.v12i1.2475

DeSchryver, M., \& Spiro, R. J. (2008). New forms of deep learning on the web: Meeting the challenge of cognitive load in conditions of unfettered exploration in online multimedia environments. In R. Zheng (ed) Cognitive Effects of Multimedia Learning (pp. 134-152). Hershey, PA: Information Science Reference/IGI Global. https://doi.org/10.4018/978-1-60566-158-2.ch008

Dickie, V. A., \& Meier, H. (2015). The Facebook tutor: Networking education. Ubiquitous Learning: An International Journal, 8(2), 15-20.

Ellefsen, L. (2015). An investigation into perceptions of Facebook-use in higher education. International Journal of Higher Education, 5(1), 160-172. https://doi.org/0.5430/ijhe.v5n1p160

European Commission (2006). Recommendation of the European Parliament and of the Council of 18 December 2006 on key competences for lifelong learning (2006/962/EC). Retrieved from https://eurlex.europa.eu/legal-content/EN/TXT/?uri=celex:32006H0962

European Commission (2007). Key competencies for lifelong learning: European Reference Framework, Office for Official Publications of the European Communities. Luxembourg. Retrieved from https://www.erasmusplus.org.uk/file/272/download

European Commission (2016). DigCompOrg. Digitally competent educational organisations. Retrieved from https://ec.europa.eu/jrc/en/digcomporg

European Commission (2018). Communication from the commission to the European parliament, the council, the European economic and social committee and the committee of the regions, on the Digital Education Action Plan. Brussels. Retrieved from https://eur-lex.europa.eu/legalcontent/EN/TXT/PDF/?uri=CELEX:52018DC0022\&from=EN

European Commission (2019). The Digital Competence Framework 2.0. Retrieved from https://ec.europa.eu/jrc/en/digcomp/digital-competence-framework

European Union (2014). Digital agenda for Europe. Retrieved from http://www.europarl.europa.eu/factsheets/en/sheet/64/digital-agenda-for-europe

Fernández, E., Leiva, J. J., \& López-Meneses, E. (2017). Training in e-skills at university. Perceptions of the students. Campus Virtuales, 6(2), 79-89.

Ferrari, A. (2012). Digital competence in practice: An analysis of frameworks. JRC Technical Reports. Institute for Prospective Technological Studies, European Union. Retrieved from https://op.europa.eu/en/publication-detail/-/publication/2547ebf4-bd21-46e8-88e9f53c1b3b927f/language-en

Ferrari, A., Neza, B., \& Punie, Y. (2014). DIGCOMP: A framework for developing and understanding digital competence in Europe. eLearning Papers, 38, 3-17. Retrieved from https://publications.jrc.ec.europa.eu/repository/bitstream/JRC83167/lb-na-26035-enn.pdf

Frangos, C., Frangos, C., \& Kiohos, A. (2010). Internet addiction among Greek university students: Demographic associations with the phenomenon, using the Greek version of Young's internet addiction test. International Journal of Economic Sciences and Applied Research, 3(1), 49-74.

Garrison, D. R. (2011). E-learning in the 21st century: A framework for research and practice. New York, NY: Taylor \& Francis.

George, D., \& Mallery, P. (2003). SPSS for Windows step by step: A simple guide and reference. Boston, MA: Allyn \& Bacon.

Gil-Flores, J. (2009). Computer use and students' academic achievement. In A. Méndez-Vilas, A. Solano Martín, J.A. Mesa González \& J. Mesa González (Eds.), Research, reflections and innovations in integrating ICT in education (pp.1235-1512). Badajoz: Formatex.

Gil-Flores, J., Rodríguez-Santero, J., \& Torres-Gordillo, J.-J. (2017). Factors that explain the use of ICT in secondary-education classrooms: The role of teacher characteristics and school infrastructure. Computers in Human Behavior, 68(3), 441-449. https://doi.org/10.1016/j.chb.2016.11.057

Gilster, P. (1997). Digital literacy. New York, NY: John Wiley.

Gisbert, M., \& Lázaro, J. L. (2015). Professional development in teacher digital competence and improving school quality from the teachers' perspective: A case study. Journal of New Approaches in Educational Research, 4(2), 115. https://doi.org/10.7821/naer.2015.7.123

Gozálvez, V., García-Ruiz, R., \& Aguaded, I. (2014). Training in media competences: A matter of ethical responsibility in higher education. Revista Interuniversitaria de Formación del Profesorado, 28(1), $17-28$. 
González-Calatayud, V., Román-García, M., \& Prendes-Espinosa, M. P. (2018). Digital competences training for university students based on Digcomp model. Edutec. Revista Electrónica de Tecnología Educativa, 65, 1-15. https://doi.org/10.21556/edutec.2018.65.1119

Gunawardena, C. N., Nolla, A. C., Wilson, P. L., Lopez-Islas, J. R., Ramirez-Angel, N., \& MegchunAlpizar, R. M. (2001). A cross-cultural study of group process and development in online conferences. Distance Education, 22(1), 85-121. https://doi.org/10.1080/0158791010220106

Heyam, A. (2014). The influence of social networks on students' performance. Journal of Emerging Trends in Computing and Information Sciences, 5(3), 200-205. https://doi.org/10.3916/C41-2013-19

Hunley, S., Evans, J., Delgado-Hachey, M., Krise, J., Rich, T., \& Schell, C. (2005). Adolescent computer use and academic achievement. Adolescence, 40(158), 307-318.

Joinson, A. M. (2008). Looking at, looking up or keeping up with people? Motives and use of Facebook. Proceedings of the Twenty-Sixth Annual SIGCHI Conference on Human Factors in Computing. Florence. Retrieved from http://digitalintelligencetoday.com/downloads/Joinson Facebook.pdf

Junco, R. (2012). The relationship between frequency of Facebook use, participation in Facebook activities, and student engagement. Computers and Education, 58, 162-171. https://doi.org/10.1016/j.compedu.2011.08.004

Junco, R., Elavsky, C. M., \& Heiberger, G. (2013). Putting twitter to the test: Assessing outcomes for student collaboration, engagement and success. British Journal of Educational Technology, 44(2), 273-287. https://doi.org/10.1111/j.1467-8535.2012.01284.x

Karlis, J. V. (2013). That's news to me: An exploratory study of the uses and gratifications of current events on social media of 18-24 year-olds. Doctoral dissertation. University of South Carolina. Retrieved from http://scholarcommons.sc.edu/etd/2347/

León Urrutia, M., Vázquez-Cano, E., \& López Meneses, E. (2017). MOOC learning analytics using realtime dynamic metrics. @TIC, 18. https://doi.org/10.7203/attic.18.10022

Leung, L., \& Lee, P. (2012). Impact of internet literacy, internet addiction symptoms, and internet activities on academic performance. Social Science Computer Review, 30(4), 403-418. https://doi.org/10.1177/0894439311435217

López-Gil, M., \& Bernal-Bravo, C. (2019). Teaching in the network society: Analysis of the digital competences of students in education at the University of Cádiz. International Journal of Educational Research and Innovation, 11, 83-100.

López Meneses, E., Vázquez-Cano, E., \& Fernández Márquez, E. (2014). Analysis of students' perception about the future social educator and social worker's intervention areas through a digital teaching method with multimedia concept maps. RED. Revista de Educación a Distancia, 41, 1-17.

López Meneses, E., Vázquez-Cano, E., \& Jaén Martínez, A. (2017). The group e-portfolio: A diachronic study at University Pablo de Olavide in Spain (2009-2015). Revista de Humanidades, 3(7), 123-152. https://doi.org/10.5944/rdh.31.2017.19076

Mäntymäki, M., \& Islam, A. K. M. N. (2014). Voyeurism and exhibitionism as gratifications from presuming social networking sites. Proceeding of the 22nd European Conference on Information Systems. Tel Aviv, Israel, June 9-11. Retrieved from http://citeseerx.ist.psu.edu/viewdoc/download?doi=10.1.1.665.8938\&rep=rep1\&type=pdf

Marín-Díaz, V., Reche, E., \& Maldonado, G. A. (2013). Advantages and disadvantages of online training. Revista Digital de Investigación en Docencia Universitaria, 7(1), 32-43. https://doi.org/10.19083/ridu.7.185

Matzat, U., \& Sadowski, B. (2012). Does the 'Do-it-yourself approach' reduce digital inequality? Evidence of self-learning of digital skills. The Information Society, 28(1), 1-12. https://doi.org/10.1080/01972243.2011.629023

Matzat, U., \& Vrieling, E. M. (2015). Self-regulated learning and social media - a 'natural alliance'? Evidence on students' self-regulation of learning, social media use, and student-teacher relationship. Learning, Media and Technology, 41(1), 73-99. https://doi.org/10.1080/17439884.2015.1064953

Mazer, J. P., Murphy, R. E., \& Simonds, C. J. (2009). The effects of teacher self-disclosure via Facebook on teacher credibility. Learning, Media and Technology, 34, 175-183. https://doi.org/10.1080/17439880902923655

Mishra, S., Draus, P., Goreva, N., Leone, G., \& Caputo, D. (2014). The impact of internet addiction on university students and its effect on subsequent academic success: A survey-based study. Issues in Information Systems, 15(1), 344-352.

Mosa, A. A., Naz'ri bin Mahrin, M., \& Ibrrahim, R. (2016). Technological aspects of e-learning readiness in higher education: A review of the literature. Computer and Information Science, 9(1), 113-127. https://doi.org/10.5539/cis.v9n1p113 
Newland, B., \& Handley, F. (2016). Developing the digital literacies of academic staff: An institutional approach. Research in Learning Technology, 24, 1-12. https://doi.org/10.3402/rlt.v24.31501

Organic Law of Education (2006). BOE-A-2006-7899. Retrieved from https://www.boe.es/buscar/pdf/2006/BOE-A-2006-7899-consolidado.pdf

Organisation for Economic Co-operation and Development (2005). The definition and selection of key competences. Executive summary. Retrieved from http://www.oecd.org/pisa/35070367.pdf

Parvathamma, N., \& Pattar, D. (2013). Digital literacy among student community in management institutes in Davanagere District, Karnataka State, India. Annals of Library and Information Studies, 60(3), 159-166.

Pérez-Sanagustín, M., Parra, D., Verdugo, R., García-Galleguillos, G., \& Nussbaum, M. (2016). Using QR codes to increase user engagement in museum-like spaces. Computers in Human Behaviour, 60, 73-85. https://doi.org/10.1016/j.chb.2016.02.012

Raines, J. (2012). The effect of online homework due dates on college student achievement in elementary algebra. Journal of Studies in Education, 2(3), 1-18. https://doi.org/10.5296/jse.v2i3.1704

Ramos, G., Chiva, I., \& Gómez, M. B. (2017). The powers in the new generation of college students: Innovation experience. Revista de Docencia Universitaria, 15(1), 37-55. https://doi.org/10.4995/redu.2017.5909

Rodríguez-García, A. M., Raso-Sánchez, F., \& Ruiz-Palmero, J. R. (2019). Digital competence, higher education and teacher training: a metaanalysis study on the Web of Science. Pixel-Bit. Revista de Medios y Educación, 54, 65-81. https://doi.org/10.12795/pixelbit.2019.i54.04

Seidman, G. (2013). Self-presentation and belonging on Facebook: How personality influences social media use and motivations. Personality and Individual Differences, 54(3), 402-407. https://doi.org/10.1016/j.paid.2012.10.009

Serrano, T. A., Biedermann, A. M., \& Santolaya, S. J. (2016). Profile, objectives, competences and future professional prospects of the students of the Degree in Industrial Design and Product Development Engineering at the University of Zaragoza. Revista de Docencia Universitaria, 14(1), 69-96. https://doi.org/10.4995/redu.2016.5908

Sharkova, N. (2014). Learning supported by technology in higher education: From experience to practice. Education Inquiry, 5(3), 429-444. https://doi.org/10.3402/edui.v5.24610

Sharma, A., \& Shukla, A.K. (2016). Impact of social messengers, especially WhatsApp, on youth: A sociological study. International Journal of Advance Research and Innovative Ideas in Education, 2(5), 367-375.

Spante, M., Hashemi, S. S., Lundin, M., \& Algers, A. (2018). Digital competence and digital literacy in higher education research: Systematic review of concept use. Cogent Education, 5, 1-21. https://doi.org/10.1080/2331186X.2018.1519143

Stanley, B. (2015). Uses and gratifications of temporary social media: A comparison of Snapchat and Facebook. Fullerton, CA: California State University.

Suhail, K., \& Bargees, Z. (2006). Effects of excessive internet use on undergraduate students in Pakistan. CyberPsychology \& Behavior, 9(3), 297-307. https://doi.org/10.1089/cpb.2006.9.297

Sultan, A., \& Christian, B. (2014). Impact of social media on personality development. International Journal of Innovation and Scientific Research, 3(2), 111-116.

Sushma, M., Peter, D., Natalya, G., Gregory, L., \& Donald, C. (2014). The impact of internet addiction on university students and its effect on subsequent academic success: A survey-based study. Issues in Information Systems, 15(1), 344-352.

Thompson, P. (2013). The digital natives as learners: Technology use patterns and approaches to learning. Computers \& Education, 65(6), 12-33. https://doi.org/10.1016/j.compedu.2012.12.022

Tondeur, J., Aesaert, K., Pynoo, B., van Braak, J., Fraeyman, N., \& Erstad, O. (2017). Developing a validated instrument to measure preservice teachers' ICT competencies: Meeting the demands of the 21st century. British Journal of Educational Technology, 48(2), 462-472. https://doi.org/10.1111/bjet.12380

Torres-Coronas, T. T., \& Vidal-Blasco, M. A. V. (2015). Students and employers' perception about the development of digital skills in higher education. Revista de Educación, 367(1), 63-90. https://doi.org/10.4438/1988-592X-RE-2015-367-283

Torres-Díaz, J., Duart, J.M., Gómez-Alvarado, H., Marín-Gutiérrez, I. \& Segarra-Faggioni, V. (2016). Internet use and academic success in university students. Comunicar, 48, 61-70. https://doi.org/10.3916/C48-2016-06

Türel, Y. K., \& Toraman, M. (2015). The relationship between internet addiction and academic success of secondary school students. Antropologist, 20(1-2), 280-288. 
United Nations Educational, Scientific and Cultural Organization (2011). UNESCO ICT Competency framework for teachers. Paris: UNESCO. Retrieved from http://unesdoc.unesco.org/images/0021/002134/213475e.pdf

Valkenburg, P. M., Peter, J., \& Schouten, A. P. (2006). Friend networking sites and their relationship to adolescents' well-being and social self-esteem. CyberPsychology \& Behavior, 9(5), 584-590. https://doi.org/10.1089/cpb.2006.9.584

Vázquez-Cano, E. (2013). The Videoarticle: New reporting format in scientific journals and its integration in MOOCs. Comunicar, 21(41), 83-91. https://doi.org/10.3916/C41-2013-08

Vázquez-Cano, E. (2014). Mobile distance learning with smartphones and apps in higher education. Educational Sciences: Theory \& Practice, 14(4), 1-16. https://doi.org/10.12738/estp.2014.4.2012

Veytia, M. (2013). Proposal to evaluate Digital Competencies in Postgraduate students using the Moodle platform. Guanajunto, México XIV Encuentro Internacional Virtual Educa.

Wang, Q., Woo, H. L., Quek, C. L., Yang, Y., \& Liu, M. (2012). Using the Facebook group as a learning management system: An exploratory study. British Journal of Educational Technology, 43(3), 428438. https://doi.org/10.1111/j.1467-8535.2011.01195.x

Warschauer, M. (1999). Electronic literacies: Language, culture, and power in online education. Mahwah, NJ: Lawrence Erlbaum Associates.

Zachos, G., Paraskevopoulou-Kollia, E.-A., \& Anagnostopoulos, I. (2018). Social media use in higher education: A review. Education Sciences, 8(4), 194. https://doi.org/10.3390/educsci8040194

Corresponding author: Esteban Vázquez-Cano, evazquez@edu.uned.es

Copyright: Articles published in the Australasian Journal of Educational Technology (AJET) are available under Creative Commons Attribution Non-Commercial No Derivatives Licence (CC BY-NCND 4.0). Authors retain copyright in their work and grant AJET right of first publication under CC BYNC-ND 4.0.

Please cite as: López Meneses, E., Sirignano, F. M., Vázquez-Cano, E, \& Ramírez-Hurtado, J. M (2020). University students' digital competence in three areas of the DigCom 2.1 model: A comparative study at three European universities. Australasian Journal of Educational Technology, 36(3), 69-88.

https://doi.org/10.14742/ajet.5583 